\title{
The Political Communication Forms Running on Caliph Ali Ibn Abi Thalib's Government
}

\author{
Khairul Hakim \\ Ph.D Student in State Islamic University of North Sumatera (UINSU), Medan, Indonesia \\ wildanansori22@gmail.com
}

\begin{abstract}
This study aims to find out the political communication forms that running on caliph Ali Ibn Abi Thalib's government. This study use qualitative method. The result shows The political agitation of the Caliph Ali in the content of his sermons and letters by stimulating and arousing the public's emotions, to be willing to make great sacrifices for the immediate goal and be willing to sacrifice the soul to realize a political ideal, when the Caliph Ali and the Shiffin war and the Jamal war. The agitation carried out by Caliph Ali did not have a negative connotation which was inciting or threatening, but was to excite or encourage his followers to win. Not agitation by making contradictions in society. While the political propaganda of the Caliph Ali was not the same as what Hitler did in World War II by making lies in spreading Nazi ideology to expand his influence and power. When Caliph Ali made a letter to Mu'awiah and the rebels at that time was not to expand power but to restore the state order based on the Qura'an and Hadith.
\end{abstract}

Keywords : political communication; caliph; Ali Ibn Abi Thalib; government

\section{Introduction}

Politics is decision making not in the interests of individuals, but in the interests of many people. Political ideals must be directed to create individuals who are committed to becoming statesmen. Because statesmen can only be achieved through sincerity and honesty. Political communication has a philosophy that is the utilization of resources whether it is human resources, infrastructure, or software to encourage the realization of a political system that carries democracy, where power runs government.

A political message is a statement delivered, both in writing and not in writing, both verbally and non-verbally, hidden or openly, both consciously and unconsciously whose contents contain political weight. Politics always contains propaganda and agitation and rhetoric. Propaganda and agitation are indistinguishable. Agitation is the dissemination of information that is done by burning emotions (blow-ups) a lot of people. While the propaganda of a communication activity that is closely related to persuasion.

Political rhetoric is different from propaganda and advertising in important matters. Rhetoric is two-way communication, one-to-one, not one-to-many; moreover, it works through inherent interpersonal relationships, which bring people together not through people as group members. Rhetoric also relies on different mechanisms for achieving social order, if propaganda involves social control mechanisms and advertising relies on convergent effectiveness, political rhetoric is a process that enables the formation of society through negotiations.

Organization as a living political arena, which contains a complex variation of individual and group interests. Prepositions from a political perspective according to Bolman quoted by Arni Muhammad are as follows: (1) Most of the important decisions in organizations include the allocation of scarce resources; (2) Organization is the combined composition of a number of individual and group interests; (3) Individual and group interests vary in their values, preferences, beliefs, information, and perceptions about relativity; (4) Organizational goals and decisions arise from the process of negotiation, negotiation and seizing positions between 
individuals and groups; (5) Because of the scarcity of resources and the existence of eternal differences, power and conflict are central to the life of the organization.

The organization is inseparable from the role of a neatly arranged system. Organization can be simply defined as a group of people who work together to achieve the same goal. In larger organizations, group members have limited duties and authority to run the organization. They become sub-systems in the organization, which are interrelated and dependent on each other, which affect the integrity of the organization and the achievement of organizational goals

But it is not impossible in an organization that there will be differences in objectives between people and sections or work units. If this is allowed to continue, then in the end the organization will face difficulties that will bring destruction to an organization. To ensure that the organization does not face the possibility that is not good, it is necessary to have good and smooth communication so that coordinating actions will be carried out properly.

The communication process can take place dialogically which enables interaction. Those involved (participants) do two messages at once, as a speaker and as a recipient, alternately through face to face. This communication process is considered by some communication experts as the oldest form of communication in the realm of communication theory, and effective, and most effective way in various forms of persuasion activities to change attitudes, beliefs and opinions for a change. With the above two theories, researchers are interested in discussing the reign of Caliph Ali $((11-41 \mathrm{H} / 632-661 \mathrm{M})$ is the most chaotic time. It was caused by the transition from the government of Usman Ibn Affan which was churned out by massive demonstrations.

\section{Review of Literature}

\subsection{Political Communication}

In essence, since humans are born they have been communicating in an effort to express themselves so that others know what they want. So there is no doubt that humans are creatures that communicate. Therefore, Muis believes that humans are always identical with creatures and users of symbols. So, humans are creatures that live for and because of communication. From the aspect of communication science, beings who are given the ability by God to shape and use symbols are humans.

Today, experts from various disciplines need communication science in the development of these disciplines. Communication aspects become significant for researchers in other fields of study in carrying out their research activities. This situation has encouraged the rapid exploration and development of communication theories over time. Although the age of Communication Studies is still relatively young, in terms of theoretical development it can outperform other disciplines that are much older.

The communication elements known in the Harold Lasswell model have confirmed that communication always has an effect or influence on the recipient to which the message is intended. Who: who or what is the source of communication, says what: what is said; this question relates to the content of the communication or what message is conveyed in the communication, to whom: this question is intended to ask who is the audience or recipient of the communication; in other words to whom the communicator speaks or to whom the message is to be conveyed, through what: means communication tools, such as talking, body movements, eye contact and touch. 


\subsection{Political Ideology}

Indeed, the political ideology of a nation is not only one source of political dynamics, but also political ideology determines the forms of a country's system. Likewise ideology and political systems are related to political communication.

In general, the term ideology is used to reflect a view of life or mental attitude. Specifically ideology usually means a set of views, attitudes and values, or an orientation of thinking about people and society.

In a certain ideology according to Alfian in Anwar Arifin's book reflected sub ideological flashes originating from interest groups that were born by social, economic, religious, ethnic and racial differences.

Islam has governed social life in full regarding all aspects of human life, both personal and social, as in the QS. al-Hujarat (49): 13, for all ages (Surah Ali 'Imran (3): 67, the world and the hereafter (Surah al-Baqarah (2): 201, 217, 220; Surah Ali' Imran (3) ): 22, and for all places and all circumstances (Surah al-Baqarah (2): 47, 122); Surah Ali'Imran (3): 103;

\subsection{Organizational Communication}

One aspect of organizational life that has never escaped the discussion of experts on organizational behavior is communication, this reality is based on the opinion that effective communication is a basic prerequisite for the creation of established goals. The position of communication within the organization, Liliweri said the position of communication within the organization actually emphasizes how an organization is constructed and maintained through the communication process.

RobIbns said the Organization is a social unit that is consciously coordinated, with a relatively identifiable boundary, which works on a relatively continuous basis to achieve a common goal or group of goals.

Meanwhile, according to Schein in Muhammad said that the organization is a rational coordination of the activities of a number of people to achieve some general goals through the division of work and function through a hierarchy of authority and responsibility. Schein also said that organizations have certain characteristics that are having structure, goals, interconnected one part with another part and depending on human communication to coordinate activities within the organization.

Furthermore Veithzal and Deddy are organizations that enable the community to achieve results that previously could not be achieved individually. The organization is a coordinated unit consisting of at least two people, functioning to achieve a certain goal or set of goals.

Organizations have different forms, some are very simple and some are very complex. In an organization there must be elements that are interconnected with one another. These elements are social structure, participants, goals, technology and environment.

In the application of the organization will have to do with the communication style used by everyone involved. Communication style is defined as a set of specialized interpersonal behaviors that are used in a particular situation. Each communication style consists of a set of communication behaviors that are used to get certain responses in certain situations. The appropriateness of the communication style used depends on the intention of the sender and the receiver's expectations. 


\subsection{Interpersonal Communication}

Interpersonal communication is the process of information exchange among a person with at least one other or usually among two people who can be directly known in turn. With the increase in people involved in communication, it becomes increasing in person perception in communication events so that it adds to the complexity of those communications.

According to Joseph A. Devito in his book The Interpersonal Communication: interpersonal communication is a process of sending and receiving messages between two people or a small group of people with some effect and feedback".

In interpersonal situations, the communication process can take place dialogically that may occur in interactions. Those involved (participant) perform two messages at a time, as speakers and as receivers, alternately through face-to-face. This communication process is considered some communication experts to be the oldest form of communication in the realm of communication theory, and the effective, and most potent way in various forms of persuasion activities to change attitudes, beliefs, and opinions for a change.

According to John O. Green, quoted by Budyatna in the Theory of Action As Sembly Theory, is one of the theories of interpersonal (interpersonal) communication that is centered on individuals. Discusses the creative nature of human behavior about how it is possible for us to hear, say, think, and do that we have never heard, said, thought, and acted before. Indeed, it can be ascertained that the nature of creativity is always present in our behavior, even though we do not know it or realize it.

The Theory of Relational Framing Theory (RFT) explains how people organize interpersonal messages to support conclusions about the relationships that occur between communicators. According to this theory, people understand relational messages by interpreting them as indicators of power-obedience or affiliation-disaffiliation. This theory views power-obedience or affiliation-disaffiliation as functional forms that help people process social messages, separate ambiguities, and draw relational conclusions. Relational messages or in other words the topic of judgments made by people about interpersonal associations. "Powerobedience" refers to the level at which one person controls, influences, or has a status above another person.

\subsection{Islamic Communication}

As it is known, the substance of general communication places communication activities and the delivery of information as commodity goods that have economic value and can be traded. In the communication activities the main communicators get more benefits. The implication is that it makes everyone free to express opinions both verbally and in writing without considering the values held by other parties.

In contrast to the perspective of Islamic communication, the alignments or significant benefits of the existence of information or communication are with the communicant (information target). Not the communicator. The substance of the delivery of information (communication) has no other purpose to create happiness and benefit of individuals and society as the target of that information or communication. Freedom of communication must be accompanied by a sense of responsibility and limited by the values held by the community, nation and state.

When talking about Islamic communication, Kholil has found a distinctive formulation by calling it a process of delivering messages or information from the communicator to the communicant using the principles and methods of communication contained in the Qura'an 
and Hadith. While referring to Abdul Halim, Kholil explained that Islamic communication is the process of delivering or passing on the true nature of Islam to the public which is carried out continuously by referring to the Qur'an and Al-Sunnah, both directly and indirectly, through intermediary public or special media, aimed at to form a true public view based on the nature of religious truth and give an impression on one's life in terms of faith, worship and muamalah.

\subsection{Caliph Ali Bin Abi Talib}

The early days of Islamic rule, exactly after the Apostlelah saw. died, the State of Medina is led by a governing institution called the caliph. The meaning of his word is that of representative, successor or office of Caliph. The term derives from the word khalf, meaning representative, substitute, and ruler. The term later emerged as a political institution in the history of early Islamic government. Synonymous with the word imamah, means government.

Priests and caliphs are two terms that the Qur'an uses to designate "leaders". The word priest is taken from the word amma-yes'ummu, meaning heading, piling and exploring. To that end Caliph Ali is often also referred to as "Imam Ali".

The word caliph is called the Qur'an twice in the letter Al-Baqarah verse 30 and the letter Shad verse 26. In plural form such as khala if is called four times (Q.S. Al-An'am verse 165, Q.S Yunus verses 14 and 73, Q.S. Fathir verse 39). Khulafa' is called three times (Q.S. AlA'raf verses 69 and 74, Q.S. Al-Naml verse 62). The forms of the words (caliphs, khala if and khulafa') each have a context of meaning in itself, which is little or much different from others.

The word caliph is rooted in the word khalafa which originally means "behind". From this the word caliph is often interpreted with "substitutes" (because the one that replaces is always behind, or comes after, which is replaced). Citing Al-Raghib Al-Isfahani, that replacing others meant carrying out something on behalf of the replaced, both along with the one he replaced and afterward. The Caliphate can be exercised as a result of the absence of place, death and inability of the person being replaced, as well as the result of the reverence given to the one replacing.

Based on the interpretation of the verses surrounding the caliph's problem his understanding can be concluded as follows: First, the caliphs are the representatives or successors of Allah Swt. on the face of the earth. Therefore, the caliphs must make Allah's will a basis for his reign. Secondly, the verses of the Qur'an give a gesture that the Caliphate consists of the authority Allah bestows Swt., the creatures handed over the task, and the region where the duty is assigned. Third, the caliphs have a number of competencies before carrying out the mandate as a leader. Fourth, a caliph has the potential to err, even can make mistakes as a result of following the passions. Prophet Adam and Prophet David were warned by Allah. so they do not follow the passions.

\section{Research Method}

At first glance the terms methodology and methods within the framework of research may appear synonymous. Whereas the notion of the methodology is broader and covers methods. Borrowing Neuman's notion, that methodology means understanding the entire process of research; including its social-organization context, philosophical assumptions, ethical principles, and political impact on new knowledge from research. Method refers to a particular set of techniques used in a study to select cases, measure and observe social life, 
collect refining data, analyzing data, and reporting results. These two terms are closely related and interdependent from each other.

More compatible research methods worn in this research are qualitative. The characteristics of qualitative research are to explain phenomena as deeply as they can through data collection. This research does not put priority to the magnitude of population or sampling (can even be just one person). If the data is already collected and already profound as well as can explain phenomena, then there is no need to look for other sampling. So qualitative research is research that describes a problem (phenomena) whose results can be generalized and this research is more concerned with the depth of analysis

\section{Discussion}

Rhetoric has a narrow sense: concerning speech, and a broad sense: the use of language, can be spoken, can also be written. Therefore, there are while people who interpret rhetoric as public speaking or speech in public. Many also assume that rhetoric not only means public speech, but also includes the art of writing. In the findings researchers many found writings or speeches that Caliph Ali made in both the appointment of governor and advice to the regional leadership through writing. Caliph Ali in writing always makes the word Amma ba'du a letter code issued by Caliph Ali. This includes one of the nonverbal communications. The letters written are adapted to the Qur'an and Hadith. In the Islamic communications review.

Kholil explained that Islamic communication is the process of delivering or passing on the true nature of the Islamic religion to the public which is carried out continuously by referring to the Qur'an and Al-Sunnah, both directly and indirectly, through general or special media intermediaries, which aim to form a general view that true based on the true nature of religion and gives an impression to one's life in the aspects of faith, worship and muamalah.

Kholil straightforwardly continued, that in fact in theoretical and practical aspects, Islamic communication can be different from general communication. Because Islamic communication is based on the Qur'an and Hadith which uphold the truth, while general communication prefers political and material benefits.

Communication experts particularly in the West want freedom of communication indefinitely, including freedom in the possession and mastery of communication infrastructure by the private party. Instead the Islamic world views information as social goods rather than sole commodities, so it is indispensable to the balance and social responsibility of the communications offender.

In the Qur'an the phrase which is similar to qaulan / al-qawl is "words". In addition, this expression is almost the same (approaching) with the understanding of communication. In other words, the Koran calls communication carried by humans is nature and plays an important role in relations between fellow social beings.

Quoting Syaukani in his commentary book, Fath Al-Qadir, Rakhmat explained that the meaning of al-bayan in the Koran is mentioned as the ability to communicate. To find out how people should communicate, key concepts must be tracked which are used by the Qura'an for communication. In addition to al-bayan, a keyword that is widely referred to as the Qura'an is al-qawl. By paying attention to the word "qaul" in the context of the command (amr), it can be concluded in six principles of communication: Qaulan Balīgan (QS 4:63), Qaulan Maisüran (QS 17:28), Qaulan Ma'rūfan (QS 4: 5), Qaulan Layyīnan (Qur'an 20:44), Qaulan Karīman (Qur'an 17:23), Qaulan Sadīda (Qur'an 4: 9; 33:70). 
First, Qaulan Baligan. The phrase qaulan balighan contains the An-Nisa verse verse 63:

"Those are they, the secrets of whose hearts Allah knoweth. So oppose them and admonish them, and address them in plain terms about their souls" (QS. An-Nisa (4): 63)

The word baligh from Arabic means up to , regarding the target, or achieving the goal. When associated with qawl (pronunciation or communication), then baligh means eloquent, clearly its meaning, light, precisely revealing what is desired. Therefore, the principle of qaulan baligan can be interpreted as an effective principle of communication. However, there is also one that interprets as "a word that is imprinting in the soul".

Like a letter 41 that says to an official:

Now, I've made you a partner in my trust, and made you my chief person. And for me there is no one else than among my more trusted relatives than you in terms of sympathy with me, helping me and respecting my trust. But whenever you see that time has attacked your misan brother.

Letter 42: To 'Umar ibn Abî Salamah al-Makhzûmî (Prophet's stepson of ummul mu'minîn Umm Salah) who served as Governor of Amir al-mu'minin (as) in Bahrain, but he shifted and replaced it with an-Nu'man ibn Ajlăn az-Zuraqî

Now, I have placed an-Nu'măn ibn 'Ajlăn az-Zuraqî in Bahrain, and have freed you from that post without something bad of you and did not criticize you, because you have managed the province well and carried out obligations. Therefore, come to me at a time when you are not suspected and not reprimanded, blamed and innocent.

Letter 43: To the matter of ibn Hubairah as-Syaibănî, Governor of Ardasyîr Khurrah (Iran)

I hear about you a thing that when you have done then you have caused God's anger and violated your faith. You hand out among the Arabs (Badui) your relatives who tend to you the property of the Muslims they collect with lemIbng and their horses and over them their blood spilled. For God's sake that grows seeds and creates living things, when this is true, then you will be humbled in my view and your weight will be light.

Letter 46: To an official

Amma ba'du, in fact you are one of those people whose help I took in upholding religion and whose help I broke the pride of the sinner, and guarded critical borders. You must seek God's help in everything that causes you anxiety.

Letters 50: Into the officers of his army

From the servant of Allah, 'Ali, Amirul Mukminin to the chief officer of the garrison.

Now, it is obligatory for an officer that the virtues he attains, or the wealth to which he has been given a special mandate, does not make him change his behavior to those below him, and that the wealth which God has bestowed upon him must increase himself in closeness to his people and anger at his brothers. 
Caliph Ali always said that he was responsible to Allah and affixed his letter with a sentence from the servant of Allah.

Saying Positive is very influential for one's happiness in whatever condition he is in. A communicator who often sends positive messages to the communicant will save a lot of capital to make positive ones. In accordance with the hadith of the Prophet from Anas Ibn Malik, in fact the Prophet was pleased when he went out on an affair to listen to those who say: may always be in demand, good luck always.

When related from the perspective of religious socioculturalism, a professional effort by which the value system, norm system, rules and religious premises are translated in such a way into a sociocultural system that is easily perceived, understood, and made as a system that regulates technically operations in sociocultural associations by humanity. Paul Tillich in Solatun's book the importance of clear mutualistic interpretation between religion and culture. In the case of Khalifah Ali's sermon, he always reminded the leaders in each region to carry out their politics in accordance with the order of the Qura'an and the Sunnah. Jalaluddin Rachmat concluded communication as a skill and an art. Communication is a skill when it is intended to move and play the camera, write speech compositions, or plan public relations organizations.

Al-Farabi in Nusrati defines politics (siyasat) is the relationship between the leader and the leader and the government service well. According to Farabi a good government is a government that is capable of instilling character and can produce true happiness for its people. While Khalifah Ghazali in Nusrati called politics as an action to improve society and give instructions to them about the right path and can save them in the world and the hereafter. Kawakibi in Nusrati interpreted politics a set of ways to manage society rationally and wisely.

Speech (khutbah) constitutes the delivery of ideas or advice to any leader of the territory that Caliph Ali did according to:

Sermon 123: Took Its Warring Followers

Place the pilgrimage man in front and hold the unpilgrim in back. Break your teeth firmly because it will derailed the sword from your headbone, and brush the side of the spear, because (thing) it will change the direction of its sharp side. Head down the eye because it strengthens the soul and reassesses the heart. Turn off the voices because (things) this will keep away the loss of spirit.

Sermon 130: Fundamentals of Acceptance of the Caliphate and the Attributes of Leaders and Government

$O$ man of different thoughts and divided hearts, whose bodies are present, but his wits are not. I will lead Ande (peacefully) to the truth, but you escape from him like goats and the sheeps run from the lion's roar. How fond it is for me to reveal to you the secrets of justice, or straighten the arches of truth.

Oh, Allah! You know that what we do is not to seek power, nor to acquire anything from the void of the world. We would rather restore the verses of Thy religion and deliver prosperity to Thy towns to have the oppressed among thy servants safe, and thy commandments that have been neglected can be enforced. Oh, my Allah! I am the first to lean (to thee) and who listens and answers (the call of Islam). No one precedes me in prayer, other than the Prophet.

You must know that whoever sways the responsibility of honor, life, the commandment of law and the leadership of the Muslims, should not be a greed, for his greed will be 
eyeing the wealth of them; nor do he mislead them with his mischief; not behave harshly in order not to keep them away with his crosswalk; it should not behave lamentably. The abundance of wealth that thus prefers one group over another; it must not accept bribery while making decisions, for (thus) it sacrifices (others) and hinders them without intercession; it must not ignore the sunah because (by doing so) it will destroy the people.

Sermon 170:Arrogant When Amirul Mukminin decided to fight the enemy with face-to-face in Shiffin, he said:

O Allah! The preserver of the high heavens and the extended space which You have made a shelter for night and day, an orbit for the sun and moon and a path for the circulating Ibnang, and to inhabit it. You have created a group of Your angels who are not tired of worshiping You. O Preserver of the earth that You have made a residence for humans and a place for the movements of insects and animals and other innumerable creatures that are visible and invisible. $O$ Preserver of the strong mountains that you have made like stakes for the earth and (means) support for humans. If you give us victory over the enemy, save us from breaking the line and keep us on the right path. But if You give them victory over us, then grant martyrdom and save us from disaster.

Where are the people who protect honor, and those who respect themselves who defend those who are respectable in times of trouble? Shame is behind you while heaven is before you.

Sermon 172: Rightful for the Caliphate (Position)

The Prophet is the messenger of Allah's revelation, the last of His prophet, the giver of (happy) news about His mercy and the reminder of His punishment.

$O$ people, who have the right of all men for this matter (i.e the Caliphate) is the most capable of them to enforce it, and who is best aware of Allah's commands about it. If a disaster is created by a disaster carrier, he will be called to repent. If he refuses, he will be fought. For my life, when the Caliph's troubles are not to be decided unless everyone is present, there will be no such thing (in the past time). But those who approve it impose a decision on the absent, such that the attending person cannot refuse and the absentee cannot vote (someone else). Know that I will fight two people, who acknowledge what is not his and others who ignore what is mandatory for him.

From a number of letters and sermons of the Caliph Ali conducted in carrying out hispolitics Ali used public relations and mass media communications. The author found a form of communication socioculturalization of religion.

One day, came Talha and Zubair to the Caliph Ali to convey the desire that had been hidden in each other's thoughts. In their conversation with Caliph Ali, they frankly said, "Yes Amiral Believers, do you know, on what basis do we pledge allegiance to you?" Caliph Ali replied "Yes, I know, on the basis of your promise to be obedient, as promised you give it to Abu Bakr, Umar and Ustman. "They replied" Yes but we pledge allegiance to you on the basis of our belief that you include both of us in government. "Caliph Ali answered firmly; not! We are you participating in contributing opinions, in upholding the truth, and in providing assistance. "From these words, Caliph Ali also used interpersonal communication. Thus the Caliph Ali aside from non-verbal communication he also made verbal communication. 


\section{Conclusion}

When related from the perspective of religious socioculturalism, a professional effort by which the value system, norm system, rules and religious premises are translated in such a way into a sociocultural system that is easily perceived, understood, and made as a system that regulates technically operations in sociocultural associations by humanity. In the case of Khalifah Ali's sermon, he always reminded the leaders in each region to carry out their politics in accordance with the order of the Qura'an and the Sunnah. The speech (sermon) is the delivery of ideas or advice to every regional leader conducted by Caliph Ali. The political rhetoric carried out by Caliph Ali, both in sermons and letters, has a high persuasive power by using decisive language to influence, positively reducing the human spirit towards truth. Caliph Ali had knowledge of human psyche, about truth, especially aspects of the truth of the matter at issue. Both in the appointment of the governor or the warnings. The political agitation of the Caliph Ali in the content of his sermons and letters by stimulating and arousing the public's emotions, to be willing to make great sacrifices for the immediate goal and be willing to sacrifice the soul to realize a political ideal, when the Caliph Ali and the Shiffin war and the Jamal war. The agitation carried out by Caliph Ali did not have a negative connotation which was inciting or threatening, but was to excite or encourage his followers to win. Not agitation by making contradictions in society. While the political propaganda of the Caliph Ali was not the same as what Hitler did in World War II by making lies in spreading Nazi ideology to expand his influence and power. When Caliph Ali made a letter to Mu'awiah and the rebels at that time was not to expand power but to restore the state order based on the Qura'an and Hadith. When associated with Herbert Blumer's opinion that propaganda can be a political campaign that deliberately invites and guides to influence / persuade people to accept a view, sentiment, or value.

In Ali's letter to Mu'awiah about the killing of Ustman is not propaganda but to find out the truth. Viewed from a political propaganda point of view can be an activity of political communication carried out in a planned and systematic way, to use suggestions (to play with emotions), for the purpose of influencing a person or group of people, audiences or larger communities (nations) to carry out or adhere to an idea (ideology, ideas to attitudes), or certain activities with their own awareness without feeling forced / forced.

\section{References}

Ali, Novel, Peradaban Komunikasi Politik: Potret Manusia Indonesia, Bandung: Remaja Rosdakarya, 1999.

Almon, Gabriel A. \& James S. Coleman, Polities of the Developing Areas, Princeton, University Press, 1990.

Azwar, Saifuddin, Metodologi Penelitian, Yogyakarta: Pustaka Pelajar, 2004.

Ali, K., Sejarah Islam: (Tarikh Pramodern), terj. Ghufron Mas'adi, Jakarta: PT RajaGrafindo persada, 1996.

Ali bin Muhammad bin Ali al-Zain al-Syari Al-Jurjani, al-Ta'rifat, cet. 1, Beirut: Da al-Kutub al-Ilmiyyah, 1403-1983.

Ash-Shalabi, Ali Muhammad, Biografi Ali Bin Abi Thalib, cet. 1, Jakarta: Pustaka Al-Kautsar, 2008. 
Ath-Thabari, Abu Ja'far Muhammad ibn Jarir ibn Yazid, Jâmi' al-Bayân'an Ta 'wîl Ay al Qur'ân. Kairo: Mathba'ah Mushtafa al-Babi al-Halabi, 1938 H.

Al-Quraibi, Ibrahim, Tarikh Khulafa', terj. Faris Khairul Anam, cet. 1, Jakarta: Qisthi Press, 2009.

Al-Hafiz Imāduddīn Abi Alfidā Ismāīl Ibnu Umar Ibnu Kas̄īr al-Qursyi ad-Dimisyqi, AlBidāyah wa an-Nihāyah, jilid X, Muhandisin Giza: Dār Hijr, 1997.

Al-Akkad, Abbas Mahmoud, Kedermawanan Khalifah Usman Bin 'Affan, terj. Bustami A. Gani, Jakarta: Bulan Bintang, 1979.

Al-Afifi, Abdul Hakim, Seribu Peristiwa Dalam Islam, terj. Irwan Kurniawan, Jakarta: Pustaka Hidayah, 2002.

Damsar, Pengantar Sosiologi Politik, Jakarta: Kencana Prenada Media Group, 2005.

Departemen Pendidikan dan Kebudayaan, Kamus Besar Bahasa Indonesia, Jakarta: Balai Pustaka, 1995.

Departemen Pendidikan Nasional, Ensiklopedi Islam, jilid 3, Jakarta: PT Ichtiar Baru Van Hoeve, 2001.

Departemen Pendidikan Nasional, Ensiklopedi Islam, jilid 5, Jakarta: PT Ichtiar Baru Van Hoeve, 2001.

Ja'far, Dialog Agama Dalam Berbagai Perspektif, Banda Aceh: Pena, 2013.

Junaedi, Fajar Komunikasi Politik: Teori, Aplikasi dan Strategi di Indonesia, cet.1, Yogyakarta: Buku Litera, 2013.

Jordac, George, Suara Keadilan: Sosok Agung Ali Bin Abi Thalib R.A., cet.4, terj. Abu Muhammad As-Sajjad, Jakarta: Lentera, 2005.

Kaban, Ramon dan Suwandi Sumartias, "Optimalisasi Komunikasi Politik Anggota DPRD Provinsi Sumatera Utara Melalui Pemanfaatan Teknologi Informasi dan Komunikasi”, dalam Irwansyah (ed), Demokrasi Masyarakat Plural, Jakarta: ISKI, 2014.

Kaelan, Metode Penelitian Kualitatif Bidang Filsafat, Yogyakarta: Paradigma, 2005.

Kantaprawira, Rusadi, Sistem Politik Di Indonesia, Bandung: Sinar Baru, 1983.

Kambey, D.C, Landasan Teori Administrasi/Manajemen: Sebuah Intisari, Manado:Yayasan Tri Ganesha Nusantara, 2010.

Kertapati, Ton, Dasar-Dasar Publisistik, Jakarta: Soeroengan, 1968.

Kincaid, Lawrence dan Wilbur Schramm, Asas-Asas Komunikasi Antar Manusia, Terj. Agus Setiadi, Jakarta: LP3ES-EWCI, 1977.

Koentjaraningrat, Masalah Perencanaan Penelitian: Metode-Metode Penelitian Masyarakat, Jakarta: PT Gramedia, 1977.

Khaliq, Farid Abdul, Fikih Politik Islam, Jakarta: Amzah, 2005.

Muhammad Arni, Komunikasi Organisasi, cet.10, Jakarta: Bumi Aksara, 2009.

, Komunikasi Organisasi, cet.13, Jakarta: Bumi Aksara, 2014.

Muis, Andi Abdul, Komunikasi Islami, cet.1. Bandung: Remaja Rosdakarya, 2001.

Mulyana, Dedy, Ilmu Komunikasi Suatu Pengantar, cet.1, Bandung: Remaja Rosdakarya, 2000

2007.

Ilmu Komunikasi Suatu Pengantar, Bandung: PT. Remadja Rosda Karya,

Muhtadin, Imamul, 'Ali Bin Abi Thalib, Pintu Gerbang Ilmu Nabi SAW, Bandung: Pustaka Hidayah, 2008.

Moleong, Lexy J., Metode Penelitian Kulitatif, Bandung: Remaja Rosdakarya, 2006. 
McNair, Brian An Introduction to Political Communication, New York: Routledge,1995.

Nazir, M., Metode Penelitian, Jakarta: Ghalia Indonesia, 2003.

Neuman, W. Lawrence, Metodologi Penelitian Sosial: Pendekatan Kualitatif dan Kuantitatif, Jakarta: Indeks, 2013.

Robbins, Stephen P., Teori Organisasi Struktur, Desain dan Aplikasi, San Diego: Prentice-Hall International, Inc, 1994.

Rasyid, Mohamad Shabirienur, Sebuah Prisma Seribu Cahaya, Jakarta: Humaniora Utama, 2000.

Rivai, Veithzal dan Deddy Mulyadi, Kepemimpinan dan Perilaku Organisasi, Ed.III, Jakarta: Raja Grafindo Persada, 2009.

Sami bin Abdullah al-Maghlouth, Jejak Khulafaur Rasyidin Ali bin Abu Thalib, terj. Fuad Syaifuddin Nur, Jakarta: Almahira, 2014.

Severin, Werner J. dan James W. Tankard, Teori Komunikasi Sejarah, Metode, dan Terapan di Dalam Media Massa, Edisi Kelima, Jakarta: Kencana, 2009.

Siagian, Sondang P, Manajemen Modern, Jakarta: Gunung Agung, 1995.

Surbakti, Ramlan, Memahami Ilmu Politik, Jakarta: PT Gramedia Pustaka Utama, 1992.

Suhelmi, Ahmad, Polemik Negara Islam: Soekarno Versus Natsir, Jakarta: Teraju, 2002.

Sunan al-Tirmidzi, juz 4, h. 43, hadis No. 217

Suryadilaga, Alfatih, dkk, Metodologi Ilmu Tafsir, Yogyakarta: Teras, 2005.

Sutanto, Astrid S., Komunikasi Sosial Di Indonesia, Jakarta: Bina Cipta, 1980

Tim Dosen Administrasi Pendidikan Bandung, Manajemen Pendidikan, Bandung: Alfabeta, 2009.

Usman, Husaini, Manajemen:Teori, Praktik, dan Riset Pendidikan, Jakarta Timur: Bumi Aksara. 2009.

Wahid, Umaimah, Komunikasi Politik, Perkembangan Teori dan Praktek, Jakarta: Widya Komunika, 2012.

"Diskursus Politik Undang-Undang Pilkada 2014 Analisis Hegemoni Counter Hegemoni antara Political Society dan Civil Society atas Hak Politik Rakyat dalam Proses Politik Indonesia", dalam Irwansyah (ed), Transformasi Komunikasi Politik, Jakarta: ISKI, 2014.

Wahid dalam Jurnal Sosiohumaniora, Volume 16 Nomor 1, Maret 2014

Zed, Mestika, Metode Penelitian Kepustakaan, Jakarta: Yayasan Obor Indonesia, 2008. 